This is an Accepted Manuscript of an article published by Taylor \& Francis Interdisciplinary Science Reviews on 06 Dec 2018, available online:

http://www.tandfonline.com/10.1080/03080188.2018.1537596

\title{
A CONCLUDING RESPONSE
}

Tim Ingold

University of Aberdeen

A few weeks ago I took part in a small workshop of likeminded scholars - including colleagues from anthropology, archaeology, sociology, geography, and science studies - to discuss how ideas of solidity and fluidity are being both mobilised and challenged in contemporary debates around materials and their meanings. ${ }^{1}$ We were all agreed that at a time of environmental crisis - with rapidly melting ice-sheets, plastic-filled oceans and the increasing incidence of extreme weather events - these debates have taken on an unprecedented urgency. However we were also only too aware that with our common intellectual formation in the disciplines of the humanities, we lacked professional expertise in the many fields of science and technology on which we were drawing for our discussion, ranging from seismology, glaciology and oceanography to chemical engineering and materials science. How would our deliberations have been affected, had experts in these sciences been present in our midst? And how might they have responded to our ideas? Then, as we were rounding up the proceedings, one of our number said something that struck a chord around the table. We should all aspire, she said, to be amateurs. ${ }^{2}$ For the amateur is literally one who studies a subject for the love of it, motivated by a sense of care, personal involvement and responsibility. The amateur finds in study a way of life, not the means by which to stage a career, yet by the same token, it is a way that cannot be dissociated from his or her whole way of living in the world.

However in a political climate wherein expertise is routinely vilified, as the self-important posturing of an academic elite, this appeal to amateurism could potentially backfire. We need to add something to it, lest we risk a descent into crude populism. Reflecting on our discussion at the workshop, the word that came to my mind was rigour. Amateur study, I thought, to be worthy of the name, must be rigorous. It brought to mind my own lifelong attempts to master the cello, which have involved years of practice, struggle, frustration, and even pain, but have nevertheless brought an immense sense of personal fulfilment. Rigour has its rewards. But then I read Amanda Ravetz's marvellous piece on 'Black Gold', and it forced me to think again. One can question the etymology: Ravetz traces the word to the Middle English variants of rig, covering everything from the strip of the medieval ploughman to the spine of an animal and the roof-ridge of a house. My dictionary, however,

\footnotetext{
${ }^{1}$ This was the workshop Solid Fluids: New Approaches to Materials and Meaning, held at the University of Aberdeen, August 27th to $29^{\text {th }}, 2018$. The workshop was convened by Cristian Simonetti and myself, and funded by the British Academy under its International Partnership and Mobility Programme.

${ }^{2}$ The speaker was Sasha Engelmann, and I am pleased to have the opportunity to acknowledge her contribution.
} 
finds the root of the word in the Latin rigere, 'to be stiff', with the further connotations of numbness, hardness, and morbidity. Whichever derivation you prefer - and perhaps they are connected - hardness and severity seem to be at the heart of it. Rigour is bereft of feeling, yields nothing to experience, and induces instant paralysis in anything living or moving with which it might come into contact. Is that the way of the so-called 'hard sciences'? Then it is one to which the amateur scholar must be resolutely opposed.

Consider the straight line, famously defined by Euclid as the shortest connection between points. Determine the points, and you have already specified the line. This line has no breadth; it is abstract and insensible. It is not like the taut strings of my cello, which have a certain weight and thickness, and which moreover bend and vibrate when bowed or plucked. It is not like the straight furrow of the ploughman that is cut as he goes along, and calls for his constant and vigilant attention so as to maintain its equidistance from, and alignment with, the adjacent rig. It is not like the perfectly straight lines that the artist Jaime Refoyo taught me to draw freehand, but only after having first instructed me in how to find a certain balance of forces and muscular tensions within my own body, calling also for a heightened perceptual awareness of my immediate surroundings. ${ }^{3}$ If there is rigour in these lines, it is neither immobile nor insentient. It lies, rather, in the precision of close attunement: in the tension of the cello string, yielding a determinate pitch on vibration; in the ploughman's attention to the field; in my attention to my body and its environs. Thus it seems that there are two varieties of rigour, virtually the opposite of one another: one that lends authority to the 'hard' sciences in their encounter with an unyielding world of objective facts; the other that calls for practised care and attentiveness in an ongoing relation between conscious awareness and lively materials.

In his essay The Assayer of 1623, Galileo Galilei declared that the book of the universe is written in the language of mathematics. ${ }^{4}$ What are we to make, then, of the rigour of mathematical thinking? Does it lie in the logical formality of a Euclid, or in the bodily movements and sensibilities of the cellist, farmer or draughtsman? Is it hard or soft? This is the question Trevor Marchand asks as he observes artist Andrew Omoding at work, overlaying and stitching an assortment of fabrics into an unruly composition. The work displays a mathematical sensibility, Marchand argues, which is not so much given in advance as emergent in the artist's explorations of the materials, and in the bodily movements involved in stitching them up. But you don't have to be an artist to do mathematics like this. We all do it in our everyday gestures, since every such gesture - insofar as it engages a sensing body with materials and tools - calls forth relations of line, surface, scale and proportion. I am with Marchand in his mission to democratise mathematics, to dispel the aura of individual genius that has grown around it, and to recognise the mathematician in every one of us. But I am not convinced that mathematicity inheres in the gesture in and of itself. To me it seems to stem, rather, from the introduction of that gesture into a field of

\footnotetext{
${ }^{3}$ Based in Barcelona, Refoyo describes himself not as an artist but as a 'geographer of thought'. See http://www.jaimerefoyo.com/index-en.html.

${ }^{4}$ Galileo Galilei, 1957, Discoveries and opinions of Galileo, trans. Stillman Drake. Garden City, NY: Doubleday Anchor.
} 
variation wherein the same or similar generative principles can be shown to be at work, yielding results that may be understood as transforms of one another.

The mathematician seeks to uncover these principles, or what are commonly called elements. This is what D'Arcy Wentworth Thompson triumphantly achieved in his studies of the growth and forms of living organisms, and what Claude Lévi-Strauss attempted perhaps with less success - in his efforts to reveal the elementary structures of kinship and, subsequently, of myth. ${ }^{5}$ It is not a reductionist endeavour, since no variation is lost in the process. It is rather a kind of condensation, which compresses the gamut of outwardly expressed forms into an inner kernel of potentially explosive intensity. The fact that Wassily Kandinsky, in his painterly explorations of point, line and plane, explained the logic of abstraction in precisely these terms, suggests a convergence, in mathematics, of science and art. ${ }^{6}$ Where, then, does anthropology fit into this? Can it, too, be both science and art? Cristina Grasseni makes a powerful and persuasive case for anthropology as 'a science of sociocultural relations'. Like any science, it must be founded in observation. For most anthropologists, this takes place in fieldwork - a sort of apprenticeship in the ways of thinking and doing particular to a community. In the field, the anthropologist in undoubtedly an amateur, drawn to a form of life through a sense of curiosity and care, tempered by personal involvement and responsiveness. He or she observes as a participant, from the inside. As with any apprenticeship, the work is rigorous, in the specific sense that it demands a thoroughgoing attentiveness. Moreover for the fieldworker, the experience is personally transformative.

It is what happens next that is problematic. For in Grasseni's account the first stage of fieldwork is followed by a second, in which the lessons learned in the first are processed into a corpus of 'anthropological knowledge', ready to be both disseminated in the anthropologist's own society and brought to bear on the banality of common sense. It is in the transition from the first stage to the second that fieldwork through participant observation is retrospectively rebranded as 'ethnography'. With that, everything changes. Lessons learned become data for analysis. The anthropologist's method - his or her personal way of working in the field - turns into 'methodology', an impersonal set of operational principles that can be formalised independently of the circumstances of application. Methodology and analysis call for rigour of a quite different kind from that which was needed in the field: the rigour not of attentive attunement but of hard, straightbacked objectivity. No longer content to be an amateur, the anthropologist now selfpresents as a professional, flaunting ethnography as the marker of his or her distinctive expertise. Lives are packaged into cases, as has happened - for example - to the life of Andrew Omoding when Marchand, perhaps without really meaning it, presents his observations of the artist's practice as an 'ethnography'. And armed with the knowledge packed into these cases, the anthropologist sees fit to pronounce with authority on matters

\footnotetext{
${ }^{5}$ D'Arcy Wentworth Thompson, 1917, On Growth and Form, Cambridge: Cambridge University Press; Claude Lévi-Strauss, 1949, Les Structures élémentaires de la Parenté, Paris: Presses Universitaires de France; 1964-71, Mythologiques, 4 vols. Paris: Plon.

${ }^{6}$ Wassily Kandinsky, 1926, Punkt und Linie zu Fläche: Beitrag zur Analyse der malerischen Elemente, München: Albert Langen.
} 
over which common sense has a grasp that is merely banal. In short, after the exposure of fieldwork, normal academic service is resumed.

I have maintained all along that there can be no observation without participation - without a close coupling, in perception and action, of the investigator with the things that capture his or her attention. ${ }^{7}$ That was how my father attended to his beloved fungi. Did that make him an ethnographer? Of course not! But the claims of anthropologists to be conducting ethnography, even in the absence of any identifiable ethnos, and on no other grounds than that their practice involves rigorously attentive, participatory observation, are scarcely more credible. Thus while I am grateful to Grasseni for her vigorous defence of anthropological normality, I remain convinced that to found anthropology in ethnography is ultimately selfdefeating. ${ }^{8}$ This does however bring me back, with Stuart McLean, to the topic of childhood. It reminds me that according to the status quo, children cannot become professionals until they grow up. The ideal of professionalism, in other words, reproduces a well-worn conception of childhood as training for adult life. In this conception, as McLean observes, every child is 'an adult-in-the-making', a potential but not-yet professional, whose formation remains incomplete. However the child-as-amateur - or more accurately perhaps, the amateur-as-child - cuts a quite different figure. He or she will never grow up. For in a world that continually evokes wonder and astonishment, every ending is a new beginning. Repudiating the contextual framings and explanatory precepts of the adult world, this child revels in what McLean calls 'interstitial meddling', jubilantly mixing up nature and nurture, tradition and modernity, the long ago and here and now.

This kind of meddling, however, is also characteristic of the storyteller, as Michael Jackson shows in his retelling of the life story of the Kuranko raconteur, Keti Ferenke. The teller does not follow a straight course from event to event but loops, deviates, circles around, neither beginning nor ending anywhere in particular. Like the life of which it tells, the story carries on, going along with rather than cutting across the flow of relations. As study is for the amateur, so storytelling is for the raconteur, a way of living life, not a presentation of evidence on which to build a case. In his narrative, Keti Ferenke charts a way through the tensions between an established social order, imbued with ancestral authority, and a sense that every life has its particular interests and idiosyncrasies. He goes not from one to the other, from the freedom and innocence of childhood to the social propriety of the elder, but in between, always balancing a sense of his own singularity with that of belonging to a social world. This, too, is a theme taken up by Heonik Kwon in his reflections on the longstanding tension, in the history of anthropological discussions of religion, between animism and totemism, the one positing the solitary human, classically a hunter-gatherer, immersed in an environment, the other the solidarity of social group, vis-à-vis the natural world. Can we find a middle way, Kwon asks, between 'the philosophy of animism' and 'the sociology of totemism'? Could it be the way of the storyteller or the child?

\footnotetext{
${ }^{7}$ Tim Ingold, 2000, The Perception of the Environment: Essays on Livelihood, Dwelling and Skill. London: Routledge, p. 108.

${ }^{8}$ Tim Ingold, 2014, 'That's enough about ethnography!' HAU: Journal of Ethnographic Theory 4(1): 383-395.
} 
In short, child and adult, amateur and professional, storyteller and ethnographer, perhaps even philosopher and sociologist, play in different worlds. The world of the former is abundant, always full to overflowing, forever overtaking itself, tending to no limit. It is a world without objects which, in folding in upon itself as it goes along - literally in its complication - gives rise to the things we perceive and encounter, folds within folds. But the world of the latter is of scarcity, of competition for finite resources, brilliantly evoked by Charles Darwin, in The Origin of Species, in his likening of the face of nature to a surface riven by innumerable wedges, 'packed close together and driven inward by incessant blows'. ${ }^{9}$ In this hard and unyielding world, the challenge is to find a gap, into which to drive another wedge. Such is the high-stakes realm of professionalised research, of 'knowledge production', which - as McLean reminds us - nowadays pervades our universities. Find a gap, drive in your wedge, make an impact, and you will be rewarded! Academia - as this realm of cut-throat competition has come to be known - is intolerant of amateurs in its midst, and will do whatever it takes to root them out. These attacks have recently become so brazen that they threaten the very future of humane scholarship. Yet precisely because, for them, scholarship cannot be divorced from life, amateurs are also activists. As a selfprofessed academic amateur, my own activism has been directed towards reclaiming the university as a place for compassionate learning, dedicated to the common good. ${ }^{10}$

I have also directed my fire, however, on some of those areas of professionalised science that supply the regime of Academia with its intellectual capital. These include evolutionary psychobiology in its current, neo-Darwinian incarnation, cognitive neuroscience and artificial intelligence. These disciplines are together complicit in a project that would see all knowledge, and the power in confers, concentrated in the corporate boardrooms and stateof-the-art laboratories of elite technoscience, while expecting the rest of humanity to play robotically to their tune. There are brave voices, in biological anthropology especially, who have been outspoken in exposing the duplicity of much of this research, and Agustin Fuentes is prominent among them. Fuentes's account of his early indoctrination into neoDarwinism, and of the intimidating response of reviewers to the perceived effrontery of challenging its premises with a more relational approach, makes for chilling reading, and chimes with my own experience. As he observes, there is nothing scientific about the steadfast adherence of neo-Darwinists to what they call the standard evolutionary model. I recall how an article of mine, along similar lines, was angrily dismissed by one reviewer - a world-leading geneticist and evolutionary biologist - who could not contain his disgust that, in a country whose scientists had discovered the structure of DNA, anyone should question the role of genetic change in human evolution. In the face of the intense conservatism of evolutionary biology, it is hard, as Fuentes admits, to sell the value of a humanistic approach. Even modest extensions to the standard model encounter fierce resistance.

Nor can much succour be drawn from the ranks of social and cultural anthropologists. Clinging to ethnography as the mark of professional identity, they have no room in the club

\footnotetext{
${ }^{9}$ Charles Darwin, 1950, On the Origin of Species by Means of Natural Selection, or, the Preservation of Favoured Races in the Struggle for Life, London: Watts (original publication 1859), p. 134.

${ }^{10}$ In 2015, I led a campaign to reclaim the University of Aberdeen, resulting in a published manifesto which helped to catalyse similar campaigns elsewhere. See https://reclaimingouruniversity.wordpress.com/.
} 
for colleagues, such as Fuentes, whose work takes them into field research with nonspeaking subjects. If you are not perceived to be doing ethnography, you're out. This, I believe, is one of the great scandals of contemporary anthropology. I have myself been shocked by the willingness of many anthropologists of sociocultural complexion to flaunt their ethnographic and political credentials while doing nothing to counter popular narratives issuing from the lavishly funded hothouses of cognitive science and evolutionary psychology. If anything, their strategy has been one of appeasement. And while this is not an accusation that I could possibly level against Alf Hornborg, it does touch upon an issue of capital importance that he raises. A relational approach such as the one I have advocated for social anthropology, and which Fuentes advocates for biological anthropology, is all very well, but how can we give it a political edge? How can it be mobilised against the infinitely more powerful and apparently unstoppable forces of global capitalism? Hornborg's entirely proper concern is that it leaves us in a state of denial, yearning for a lost world where person and organism were one, emerging from within a unitary field of relations in which humans and non-humans are seamlessly joined. The world we currently inhabit, he insists, is not like that at all. It is rather constitutionally divided, between nature and society.

Ecological relations, according to Hornborg, are two-sided: both semiotic and material. With some justification, he argues that contemporary anthropological deliberations on nature and society, which by and large have sought to dissolve the boundary between them, have emphasised only the semiotic side, the traffic in signs, while neglecting the flows of energy and circulations of materials. It is no use pretending that the matrices of semiotic and material relations coincide, since under conditions of global capitalism they manifestly do not. Indeed we are all caught up materially in circuits of commodity exchange, the reach of which vastly exceeds the bounds of lived experience. Yet to my mind the source of the problem lies not in the neglect of materials and energy but in the very 'top-slicing' that siphons meaning into a distinct realm of signs, on the far side of the material world. For Hornborg it is axiomatic that there can be no meaning without signs. In this he takes his cue from the eco-semiotics of Jakob von Uexküll, according to whom every creature, casting its perceptual lens on the things it encounters, inhabits its own bubble of subjectivity, its Umwelt. But I have always preferred the ecological psychology of James Gibson. Perceptual experience, for Gibson, does not lie on the far side of material reality; it is reality as it is taken up in the lives of this or that creature. Meaning, therefore, is not bestowed upon the world but drawn from it, in what it affords the creature in carrying on its life. ${ }^{11}$

This does not, of course, invalidate Hornborg's point that ecology in inherently political, or that in this time of global crisis, the political stakes could not be higher. But it does suggest that globalisation has not so much transformed the relation between material and semiotic aspects of human ecological relations as set up an unprecedented tension between corporate capital and human labour in the appropriation and exploitation of environmental

\footnotetext{
11 Jakob von Uexküll, 2010, A Foray into the Worlds of Animals and Humans: with A Theory of Meaning, trans. Joseph D. O'Neil, Minneapolis, MN: University of Minnesota Press; James J Gibson, 1979, The Ecological Approach to Visual Perception, Boston, MA: Houghton Mifflin. On the comparison between von Uexküll and Gibson, see Tim Ingold, 2011, Being Alive: Essays on Movement, Knowledge and Description, Abingdon: Routledge, pp. 77-80.
} 
affordances. This has made a few fabulously wealthy, enhanced health and prosperity for many, while driving even more into mounting debt, chronic insecurity and grinding poverty. It has fuelled escalating military conflict and massive environmental destruction. Political ecology can reveal the logics of engineering and capitalism that have brought the world to this critical point. But it will do nothing to bring them down. It will not tell us how we might relate differently to the environment, live more sustainably, or pass on a habitable world to coming generations. I believe the only way to change course for the future is to pay renewed attention to the people and things around us, to listen to what they have to say, to learn, and to respond in kind. This is not Romantic whimsy; it is a call to arms. It is an acknowledgement that in politics, too, we should be amateurs. And I would wager that an amateur politics, carried on by way of art and other forms of participatory action, will do more to change things for the better than any amount of expert academic analysis. 